Ethiopian Journal of Environmental Studies \& Management 8(6): 708 - 719, 2015.

ISSN:1998-0507

doi: http://dx.doi.org/10.4314/ejesm.v8i6.9

Submitted: May 03, 2015

Accepted: September 08, 2015

\title{
INFRASTRUCTURAL DEVELOPMENT DIMENSION OF URBAN PROSPERITY IN SELECTED SETTLEMENTS OF OGUN STATE, NIGERIA
}

\author{
*FOSUDO, P.O., ${ }^{1}$ POPOOLA, A.E. ${ }^{2}$ and AGUNLOYE, 0.0. ${ }^{2}$ \\ ${ }^{1}$ Department of Urban and Regional Planning, School of Environmental Studies, Lagos State \\ Polytechnic, Lagos Nigeria \\ ${ }^{2}$ Department of Urban and Regional Planning, Faculty of Environmental Sciences, University \\ of Lagos, Nigeria
}

\begin{abstract}
This study investigated the extent of urban prosperity (Infrastructural Development) using residents' perceptions in selected settlements (Ota and Agbado) of Ogun State, Nigeria. The study adopted the survey research design (majorly questionnaire). The sample frame consisted of 4,375 households in Ota (Otun) and 3,312 households in Oke-Aro (Agbado Core) which translates to 7,687 households. The sample size was 722 households' heads. The method of data analysis included frequency tables and likert scale outputs through Statistical Package for Social Science (SPSS). Based on the findings, core residential area has majority (73\%) of dwellers as indigenes while 54\% were holders of secondary certificates. The study found that $49.3 \%$ were self-employed as the major (56\%) housing type design was bungalow. From the Likert scale outputs, the study revealed that the extent of urban prosperity in terms of infrastructure (public Service) were health infrastructure with 3.36 Residents' Perception Index (RPI), public school standard with $3.25 \mathrm{RPI}$ and road transport with $3.06 \mathrm{RPI}$, Also, the extent of urban prosperity in terms of infrastructures (Housing) with built as planned has 3.95 RPI and housing affordability with 3.62 RPI respectively. It was concluded that, urban settlements (Otun in Ota and Oke-Aro in Agbado) have tendency of being urban prosperous centers considering the RPI for policy formulation.
\end{abstract}

Key Words: Development, Infrastructure, Settlements, Urban Prosperity

\section{Introduction}

One veritable parameter of assessment and indicator of status of any spatial system, especially urban system is the state of infrastructure. The efficiency of any form of human activity system, including an urban area, largely depends on the provision of efficient infrastructural facilities and services (Babarinde, 1998). Aside from being a major pointer of environmental quality, urban infrastructure is a critical agent for the socio-economic development of any urban area (Okusipe, 1999). It plays an important and indispensable role in the economic, social and environmental aspects of life of an urban setting. It has a manifest impact on the quality of life. It is a backbone of any economy; industries need it to effectively and efficiently drive their production processes (Adebayo, 2006).

Urban infrastructure covers a wide range of services and facilities, namely electricity, water, roads, waste disposal,

*Corresponding author: Fosudo, P.O.

Email: ladefosudo@yahoo.com 
drainage, communication, primary health services, schools and housing as the key ones. These are more often provided by the government. Where urban infrastructure is adequately provided and efficiently managed, productive and profitable land uses are usually attracted towards such area leading to better rent offers. Nubi (2002) describes infrastructure as the aggregate of all facilities that allow a city to function effectively. It is also seen as a wide range of economic and social facilities crucial to creating an enabling environment for economic growth and enhances quality of life. They include housing, electricity, pipeborne water, drainage, waste disposal, roads, sewage, health, education, telecommunications and institutional structures like police station, firefighting stations, banks and post office. It is simply the engine needed to drive the city. Irrespective of the forms of definitions offered, the common element include physical structures, facilities or utilities that are put in place by private or public involvement and expenditure aimed at facilitating the effective functioning of the society (Adebayo, 2006).

Cities with deficient infrastructure will be adversely affected on many fronts (UNHabitat, 2013); with low level of prosperity, sustainability and productivity. For instance, an inadequate water and sanitation facility brings about deterioration of the urban environment, complimenting the burden of disease for the urban poor, particularly in slums and squatter settlements. Deficient infrastructure heightens cost of doing business in such urban areas and reduces business productivity by as much as 40 per cent; the impact can be as significant as those of crime, bureaucracy, corruption or financial market constraints (UN-Habitat, 2013).
It is from the fore-going that this study investigated the extent of urban prosperity in terms of infrastructural development in selected settlements of Ogun State (Agbado and Ota), Nigeria.

\section{Study Area}

The study was carried out in Ota area of Ado Odo/ Ota Local Government Area and Agbado area in Ifo Local Government Area of Ogun State due to their proximity to Lagos State. These are both fast growing peri-urban areas close to Lagos has the natural endowment to be called prosperous settlements. The areas exhibits polycentric characteristics and such growth in population increases land expansion to peri-urban of the Ogun state along the Expressways and Railways. The study basically deals with urban prosperity of these core urban settings. Ota has grown strongly in its physical extent along LagosAbeokuta Expressway which runs in a north-south direction from River Ilo along the state boundary with Lagos and extends to a distance of about $4.5 \mathrm{~km}$ terminating at Ijako. The physical extent of the town along Idi-roko Road which runs in an eastwest direction extends west ward from Sango to a distance of about $11.5 \mathrm{~km}$ terminating at river Iju with Canaan land being the most prominent land use.

Ota home one of most viable industrial estate in Ogun state, which reflected in the socio-economic and directly brought about rapid expansion. The Ogun State Regional Plan categorized the areas as one of the Development Pressure Area (DPA).The Development Pressure Area, DPA, was defined in the Conceptual Regional Plan of Ogun state as the areas of close proximity to the north of Lagos and under severe development pressure from the neighbouring Lagos metropolis. Ota is situated near the boundary of Lagos State and has steadily grown to be the largest 
industrial town in Ogun State, largely as a result of its nearness to Lagos. It is located within the tropical zone lying between $6^{\circ}$ $47^{\prime}$ north of the equator and $2^{\circ} 33^{\prime}$ east and $3^{\circ} 18^{\prime}$ east of the Greenwich Meridian covering a land area of 1,263 squares kilometer, it has a terrain of 1,101 square kilometer. (Ado-Odo/Ota Local Government Economic summit, 2010). The Oral tradition has it that Ota was founded in about 1835 by the Aworis (an indigenous group) that originated from Ile-Ife, the cradle of Yoruba's. The population figure of Otta in 1963 was put at 14,248, in 1991 was 103, 32 and when the 2006 National Population Census was conducted it was put at 142,793. CPMS (2008). The growth of Otta could traced to the development of industrial estates, religious worship centers, government housing estate, universities, access to border towns and most importantly a nodal town on LagosAbeokuta Expressway.

On the other hand, Agbado town has grown strongly in its physical extent along the railway station, north to Iju_Ishaga of Lagos State and extends to a distance of about $6.5 \mathrm{~km}$ terminating at Akute. The physical extent of the town along Ijoko Road which runs in an south direction extends west ward from Ijaye-Ojokoro of Lagos State. Population figure of 35,470 was recorded 1991 and 49,016 in 2003 (National Population Commission, 1998). It consists of; Oke-Aro, Ibaragun, and Matogbun, Aboru etc., shares boundary with Ado-Odo /Ota Local Government Area of Ogun State and Ifako-Ijaiye Local Government in Lagos State.

\section{Methodology}

Data for this study were obtained from two sources namely: the primary data source (questionnaire) and secondary data obtained from reports, (published and unpublished sources), textbooks, journals, file of government agencies and UNHabitat, State of the World's cities 2012/2013 and Internet are part of the secondary sources of data. The total sample frame consists of 4,375 households in Ota (Otun) and 3, 312 households in Oke-Aro (Agbado Core) which translates to 7,687 households. The sample size was 722 (768) households' heads. The sample size was calculated using the sampling theory of Yamane (1967) this was calculated as 368 per sampled area. Based on the sample size, sets of questionnaire were administered. The study adopted systematic random sampling amongst the size. The sampling procedure entailed the identification of study areas, division into six strata and selection of six streets per stratum. Household heads for interview within each street were thus selected at random. The method of data analysis included frequency tables showing values and ratings of variables/ factors. The outputs were displayed in likert scale of five points.

\section{Results and Discussion}

The connection of services to Oke-Aro shows that; $23.6 \%$ Strongly Dissatisfied, $25.4 \%$ Dissatisfied, $9.3 \%$ were Moderately satisfied, $32.1 \%$ Satisfied and $9.6 \%$ Strongly Satisfied while in Otun, it shows that $8.5 \%$ are Strongly Dissatisfied, $65.9 \%$ are Dissatisfied, $22.3 \%$ were neutral and $3.3 \%$ Satisfied. The results revealed that a higher percentage responds to dissatisfied (see Table 1).

Perception on Health Infrastructures and their Functionality

For the perception on heath infrastructures and its functionality results reveals that in Oke-Aro shows that; $14.1 \%$ Strongly Dissatisfied, $23.4 \%$ Dissatisfied, $10.7 \%$ were Moderately satisfied, $43.4 \%$ Satisfied , $7.6 \%$ Strongly Satisfied and 0.8 
$\%$ were indifferent while in Otun, it shows that; $32.4 \%$ were neural and $67.6 \%$ Satisfied. A higher percentage of respondents declared Satisfied to the fact the health infrastructures are very commendable.

\section{Perception on Public School Standard}

Results of respondents perception as regards public school standard in Oke-Aro that; $9.9 \%$ are Strongly Dissatisfied, 26.8 \% Dissatisfied, $25.6 \%$ were Moderately satisfied, 24. $8 \%$ Satisfied, $11.7 \%$ Strongly Satisfied and $0.8 \%$ were indifferent while in Otun, its shows that $12.3 \%$ are Strongly Dissatisfied, $4.1 \%$ Dissatisfied, $13.6 \%$ were Moderately satisfied, $60.5 \%$ Satisfied and $9.5 \%$ Strongly Satisfied. The majority of the respondents are Satisfied with the fact the public school in settlements were of a good standard in terms of structures and academic qualifications of teachers.

Respondents Perception on Road and Transport Infrastructure

The result on road and transport infrastructures in Oke-Aro reveals that; $27.0 \%$ are Strongly Dissatisfied, $35.2 \%$ Dissatisfied,11.8 \% are Moderately satisfied, 23.4\% Satisfied and $2.6 \%$ Strongly Satisfied while in Otun, its shows that $12.8 \%$ Strongly Dissatisfied, $0.5 \%$ Dissatisfied, $12.0 \%$ were neural $50.4 \%$ Satisfied and $24.3 \%$ Strongly Satisfied. Majority of the respondents testified to the fact the road and transport infrastructures in the settlement are commendable especially in Ota and the ongoing road project by the state.

Table 1: Respondents' Response on Infrastructure Development

\begin{tabular}{|c|c|c|c|c|c|c|c|c|}
\hline \multirow[b]{2}{*}{ Variables } & & \multicolumn{6}{|c|}{ Frequency } & \multirow[b]{2}{*}{ Total } \\
\hline & & SD & $\mathrm{D}$ & MS & $\mathrm{S}$ & SS & I & \\
\hline \multirow{3}{*}{$\begin{array}{l}\text { connected to } \\
\text { service } \\
\text { (Water) }\end{array}$} & $\begin{array}{l}\text { Agbado } \\
\text { (Oke Aro) }\end{array}$ & $\begin{array}{l}84 \\
(23.6 \%)\end{array}$ & $\begin{array}{l}90 \\
(25.4 \%)\end{array}$ & $\begin{array}{l}33 \\
(9.3 \%)\end{array}$ & $\begin{array}{l}114 \\
(32.1 \%)\end{array}$ & $\begin{array}{l}34 \\
(9.6 \%)\end{array}$ & & 355 \\
\hline & Ota (Otun) & $\begin{array}{l}31 \\
(8.5 \%)\end{array}$ & $\begin{array}{l}242 \\
(65.9 \%)\end{array}$ & $\begin{array}{l}82 \\
(22.3 \%)\end{array}$ & $\begin{array}{l}12 \\
(3.3 \%)\end{array}$ & & & 367 \\
\hline & Total & 115 & 332 & 115 & 126 & 34 & & 722 \\
\hline \multirow[t]{3}{*}{$\begin{array}{l}\text { Health } \\
\text { infrastructure }\end{array}$} & $\begin{array}{l}\text { Agbado } \\
\text { (Oke Aro) }\end{array}$ & $\begin{array}{l}50 \\
(14.1 \%)\end{array}$ & $\begin{array}{l}83 \\
(23.4 \%)\end{array}$ & $\begin{array}{l}38 \\
(10.7 \%)\end{array}$ & $\begin{array}{l}154 \\
(43.4 \%)\end{array}$ & $\begin{array}{l}27 \\
(7.6 \%)\end{array}$ & $\begin{array}{l}3 \\
(0.8 \%)\end{array}$ & 355 \\
\hline & Ota (Otun) & & & $\begin{array}{l}119 \\
(32.4 \%)\end{array}$ & $\begin{array}{l}248 \\
(67.6 \%)\end{array}$ & & & 367 \\
\hline & Total & 50 & 83 & 157 & 402 & 27 & 3 & 722 \\
\hline $\begin{array}{l}\text { Standard } \\
\text { Public }\end{array}$ & $\begin{array}{l}\text { Agbado } \\
\text { (Oke Aro) }\end{array}$ & $\begin{array}{l}35 \\
(9.9 \%)\end{array}$ & $\begin{array}{l}95 \\
(26.8 \%)\end{array}$ & $\begin{array}{l}91 \\
(25.6 \%)\end{array}$ & $\begin{array}{l}88 \\
(24.8 \%)\end{array}$ & $\begin{array}{l}43 \\
(11.7 \%)\end{array}$ & $\begin{array}{l}3 \\
(0.8 \%)\end{array}$ & 355 \\
\hline Schools & Ota (Otun) & $\begin{array}{l}45 \\
(12.3 \%)\end{array}$ & $\begin{array}{l}15 \\
(4.1 \%)\end{array}$ & $\begin{array}{l}50 \\
(13.6 \%)\end{array}$ & $\begin{array}{l}222 \\
(60.5 \%)\end{array}$ & $\begin{array}{l}35 \\
(9.5 \%)\end{array}$ & & 367 \\
\hline \multirow{4}{*}{$\begin{array}{l}\text { Road and } \\
\text { Transportation } \\
\text { infrastructure }\end{array}$} & Total & 80 & 110 & 141 & 310 & 78 & 3 & 722 \\
\hline & $\begin{array}{l}\text { Agbado } \\
\text { (Oke Aro) }\end{array}$ & $\begin{array}{l}96 \\
(27.0 \%)\end{array}$ & $\begin{array}{l}125 \\
(35.2 \%)\end{array}$ & $\begin{array}{l}42 \\
(11.8 \%)\end{array}$ & $\begin{array}{l}83 \\
(23.4 \%)\end{array}$ & $\begin{array}{l}9 \\
(2.6 \%)\end{array}$ & & 355 \\
\hline & Ota (Otun) & $\begin{array}{l}47 \\
(12.8 \%)\end{array}$ & $\begin{array}{l}2 \\
(0.5 \%)\end{array}$ & $\begin{array}{l}44 \\
(12.0 \%)\end{array}$ & $\begin{array}{l}185 \\
(50.4 \%)\end{array}$ & $\begin{array}{l}89 \\
(24.3 \%)\end{array}$ & & 367 \\
\hline & Total & 143 & 127 & 85 & 268 & 98 & & 722 \\
\hline
\end{tabular}

NB: SD = (Strongly Dissatisfied), D = (Dissatisfied) MS = (Moderately Satisfied), S = (Satisfied), $\mathrm{SS}=($ Strongly Satisfied $)$ and $\mathrm{I}=($ Indifferent $)$. 
Table 2: Perception Indexes of Respondents' on Infrastructure Development in the Study Areas

\begin{tabular}{|c|c|c|c|c|c|c|c|c|c|}
\hline & \multicolumn{4}{|c|}{ Rating and Weight Value } & \multicolumn{5}{|c|}{ Deviation } \\
\hline Factors & $\mathrm{SS}(5)$ & $\mathrm{S}(4)$ & MS(3) & $\mathrm{DS}(2)$ & SDs $(1)$ & SWV & RPI & RPI-PPI & (RPI-PPI) \\
\hline Health & 27 & 402 & 157 & 83 & 50 & 2430 & 3.36 & 0.32 & 0.1024 \\
\hline Infrastructure & & & & & & & & & \\
\hline $\begin{array}{l}\text { Public school } \\
\text { Standard }\end{array}$ & 78 & 310 & 141 & 110 & 80 & 2353 & 3.25 & 0.21 & 0.0441 \\
\hline $\begin{array}{l}\text { Road and } \\
\text { Transport }\end{array}$ & 98 & 268 & 85 & 127 & 143 & 2214 & 3.06 & 0.02 & 0.0004 \\
\hline $\begin{array}{l}\text { Connectivity to } \\
\text { service }\end{array}$ & 34 & 126 & 115 & 332 & 115 & 1798 & 2.49 & -0.55 & 0.3025 \\
\hline Total & & & & & & & 12.16 & & 0.4494 \\
\hline
\end{tabular}

The highest of the perception components from the Likert scale output of infrastructure dimensions are; health infrastructures (3.36), public school standard (3.25) and road and transport (3.06), are major components of urban prosperity in the study area

\section{Infrastructural Development Dimension (Housing)}

This section discusses the housing aspect of infrastructural development in a study area. This social aspect focused on home satisfaction, housing affordability, living space, putting up rent, meeting up with initial plan.

\section{Perception on Home Satisfaction}

The result of respondents' on home satisfaction in Oke-Aro shows that; $1.9 \%$ are Strongly Dissatisfied, $13.0 \%$ Dissatisfied, $12.1 \%$ were Moderately satisfied, $47.3 \%$ Satisfied and $25.9 \%$ are Strongly Satisfied, while in Otun, its shows that $17.2 \%$ Strongly Dissatisfied, $15.3 \%$ Dissatisfied, $21.8 \%$ were Moderately satisfied, $45.7 \%$ Satisfied. The majority of the respondents Satisfied with their home.

\section{Perception on Affordability of Housing}

The result of affordability of housing in Oke-Aro shows that; $2.8 \%$ are Strongly Dissatisfied, $11.5 \%$ Dissatisfied, and $9.0 \%$ were Moderately satisfied, $44.5 \%$ Satisfied, $32.1 \%$ Strongly Satisfied while in Otun, its shows that $6.5 \%$ Dissatisfied, $25.1 \%$ were Moderately Satisfied, 61.3\% Satisfied and 7.1\% Strongly Satisfied Majority of the respondents are Satisfied with affordable housing in the area.

\section{Perception on Living Space for the Family} Based on living space for family, the result in Oke-Aro shows that; $5.6 \%$ Strongly Dissatisfied, $8.2 \%$ Dissatisfied, and 26.2\% were Moderately satisfied, $44.5 \%$ Satisfied and $14.9 \%$ Strongly Satisfied while in Otun, its shows that $4.1 \%$ Strongly Dissatisfied, 20.7\% Dissatisfied, and 26.2 $\%$ were was Moderately satisfied, $45.2 \%$ Satisfied and $3.8 \%$ Strongly Satisfied with the fact that there is enough living space for their household.

Perception on Letting Out of Apartment or Shops

Based on un-occupied rooms/shops for rent by the landlords in Oke-Aro shows that; $5.9 \%$ Strongly Dissatisfied, $17.2 \%$ Dissatisfied, $7.6 \%$ were Moderately satisfied, $42.5 \%$ Satisfied and $24 \%$ Strongly Satisfied and $2.8 \%$ were indifferent while in Otun, its shows that $3.3 \% \quad$ Strongly Dissatisfied, $40.0 \%$ Dissatisfied, and $28.1 \%$ were Moderately 
satisfied, $24.8 \%$ Satisfied and $3.8 \%$ Strongly Satisfied . Majority of respondents who are Landlords will be interested in letting out the un-occupied rooms and shops for more income from their properties.

\section{Original Building Plan}

The result showing whether the building complied with initial building plan in Oke-Aro shows that; $4.8 \%$ Strongly
Dissatisfied, $11.8 \%$ Dissatisfied, $13.0 \%$ were Moderately satisfied, $51.3 \%$ Satisfied and $18.3 \%$ Strongly Satisfied and $0.8 \%$ were indifferent in Otun, its shows that 4.1 $\%$ Strongly Dissatisfied, and $3.8 \%$ were Moderately satisfied, $50.4 \%$ Satisfied and $41.7 \%$ Strongly Satisfied. Majority of respondents who are Landlords built as planned.

Table 3: Infrastructure development (Housing)

\begin{tabular}{|c|c|c|c|c|c|c|c|c|}
\hline \multirow[b]{2}{*}{ Variables } & & \multicolumn{6}{|c|}{ Frequency } & \multirow[b]{2}{*}{ Total } \\
\hline & & SD & $\mathrm{DS}$ & MS & $\mathrm{S}$ & SS & I & \\
\hline \multirow{4}{*}{$\begin{array}{l}\text { Home } \\
\text { Satisfaction }\end{array}$} & Agbado & 6 & 46 & 43 & 168 & 92 & & 355 \\
\hline & (Oke Aro) & $(1.7 \%)$ & $(13.0 \%)$ & $(12.1 \%)$ & $(47.3 \%)$ & $(25.9 \%)$ & & \\
\hline & Ota (Otun) & $\begin{array}{l}63 \\
(17.2 \%)\end{array}$ & $\begin{array}{l}56 \\
(15.3 \%)\end{array}$ & $\begin{array}{l}80 \\
(21.8 \%)\end{array}$ & $\begin{array}{l}168 \\
(45.7 \%)\end{array}$ & & & 367 \\
\hline & Total & 69 & 102 & 123 & 336 & 92 & & 722 \\
\hline \multirow{4}{*}{$\begin{array}{l}\text { Housing } \\
\text { Affordability }\end{array}$} & Agbado & 10 & 41 & 32 & 158 & 114 & & 355 \\
\hline & (Oke Aro) & $(2.8 \%)$ & $(11.5 \%)$ & $(9.0 \%)$ & $(44.5 \%)$ & $(32.1 \%)$ & & \\
\hline & Ota (Otun) & & $\begin{array}{l}24 \\
(6.5 \%)\end{array}$ & $\begin{array}{l}92 \\
(25.1 \%)\end{array}$ & $\begin{array}{l}225 \\
(61.3 \%)\end{array}$ & $\begin{array}{l}26 \\
(7.1 \%)\end{array}$ & & 367 \\
\hline & Total & 10 & 65 & 124 & 383 & 140 & & 722 \\
\hline \multirow[t]{3}{*}{ Living Space } & $\begin{array}{l}\text { Agbado } \\
\text { (Oke Aro) }\end{array}$ & $\begin{array}{l}20 \\
(5.6 \%)\end{array}$ & $\begin{array}{l}29 \\
(8.2 \%)\end{array}$ & $\begin{array}{l}95 \\
(26.8 \%)\end{array}$ & $\begin{array}{l}158 \\
(44.5 \%)\end{array}$ & $\begin{array}{l}53 \\
14.9 \%)\end{array}$ & & 355 \\
\hline & Ota (Otun) & $\begin{array}{l}15 \\
(4.1 \%)\end{array}$ & $\begin{array}{l}76 \\
(20.7 \%)\end{array}$ & $\begin{array}{l}96 \\
(26.2 \%)\end{array}$ & $\begin{array}{l}166 \\
(45.2 \%)\end{array}$ & $\begin{array}{l}14 \\
(3.8 \%)\end{array}$ & & 367 \\
\hline & Total & 30 & 105 & 191 & 324 & 67 & & 722 \\
\hline \multirow[t]{3}{*}{$\begin{array}{l}\text { Rooms / } \\
\text { Shop to Let }\end{array}$} & $\begin{array}{l}\text { Agbado } \\
\text { (Oke Aro) }\end{array}$ & $\begin{array}{l}21 \\
(4.1 \%)\end{array}$ & $\begin{array}{l}61 \\
(17.2 \%)\end{array}$ & $\begin{array}{l}27 \\
(7.6 \%)\end{array}$ & $\begin{array}{l}151 \\
(42.5 \%)\end{array}$ & $\begin{array}{l}85 \\
(24.0 \%)\end{array}$ & $\begin{array}{l}10 \\
(2.8 \%)\end{array}$ & 355 \\
\hline & Ota (Otun) & $\begin{array}{l}12 \\
(3.3 \%)\end{array}$ & $\begin{array}{l}147 \\
(40.0 \%)\end{array}$ & $\begin{array}{l}103 \\
(28.1 \%)\end{array}$ & $\begin{array}{l}91 \\
(24.8 \%)\end{array}$ & $\begin{array}{l}14 \\
(3.8 \%)\end{array}$ & & 367 \\
\hline & Total & 33 & 208 & 130 & 242 & 99 & 10 & 722 \\
\hline \multirow[t]{3}{*}{$\begin{array}{l}\text { Initial } \\
\text { building plan }\end{array}$} & $\begin{array}{l}\text { Agbado } \\
\text { (Oke Aro) }\end{array}$ & $\begin{array}{l}17 \\
(4.8 \%)\end{array}$ & $\begin{array}{l}42 \\
(11.8 \%)\end{array}$ & $\begin{array}{l}46 \\
(13.0 \%)\end{array}$ & $\begin{array}{l}182 \\
(51.3 \%)\end{array}$ & $\begin{array}{l}65 \\
(18.3 \%)\end{array}$ & $\begin{array}{l}3 \\
(0.8 \%)\end{array}$ & 355 \\
\hline & Ota (Otun) & $\begin{array}{l}15 \\
(4.1 \%)\end{array}$ & & $\begin{array}{l}14 \\
(3.8 \%)\end{array}$ & $\begin{array}{l}185 \\
(50.4 \%)\end{array}$ & $\begin{array}{l}153 \\
(41.7 \%)\end{array}$ & & 367 \\
\hline & Total & 32 & 42 & 60 & 367 & 218 & 3 & 722 \\
\hline
\end{tabular}


Table 4: Perception Index of Residents on Infrastructure Development (Housing)

\begin{tabular}{|c|c|c|c|c|c|c|c|c|c|}
\hline & \multicolumn{5}{|c|}{ Rating and Weight Value } & \multicolumn{4}{|c|}{ Deviation } \\
\hline Factors & $\mathrm{SS}(5)$ & $\mathrm{S}(4)$ & $\operatorname{MS}(3)$ & $\mathrm{DS}(2)$ & SDs(1) & SWV & RPI & RPI-PPI & (RPI-PPI) \\
\hline $\begin{array}{l}\text { Built } \\
\text { planned }\end{array}$ & 218 & 367 & 60 & 42 & 32 & 2854 & 3.95 & 0.45 & 0.2025 \\
\hline $\begin{array}{l}\text { Housing } \\
\text { Affordability }\end{array}$ & 140 & 383 & 124 & 65 & 10 & 2620 & 3.62 & 1.02 & 0.0144 \\
\hline $\begin{array}{l}\text { Family Living } \\
\text { Space }\end{array}$ & 67 & 324 & 191 & 105 & 30 & 2444 & 3.38 & -0.12 & 0.0144 \\
\hline $\begin{array}{l}\text { Home } \\
\text { Satisfaction }\end{array}$ & 92 & 336 & 123 & 102 & 69 & 2446 & 3.38 & -0.12 & 0.0144 \\
\hline $\begin{array}{l}\text { Room/Shop } \\
\text { for rent }\end{array}$ & 99 & 242 & 130 & 208 & 33 & 2302 & 3.18 & -0.32 & 0.1024 \\
\hline Total & & & & & & & 17.51 & & 1.3481 \\
\hline
\end{tabular}

$$
\mathrm{RPI}=17.51, \mathrm{PPI}=\frac{\mathrm{RPI}=17.51}{(\mathrm{~N}=5)} 5
$$$$
=3.50
$$

Computation of PI values in Table 4

Column 1: Factors that shows Infrastructure Development dimension (Housing) in the area

Column 2: Variables that rated strongly satisfied

Column 3: Variables that rated satisfied

Column 4: Variables that rated moderately satisfied or Moderate

Column 5: Variables that rated dissatisfied Column 6: Variables that rated strongly dissatisfied

Column 7: Addition of the variables of infrastructure development dimension with their levels of satisfaction and their respective weight values. For instance, for family living space $67(5)+324(4)+191$ (3) $+105(2)+30(1)=2444$

Column 8: Perception index of the variables of infrastructure development dimension with their levels of satisfaction and their respective weight values, equals summation of weight value (SWV) divided by the addition of individual satisfaction on the variable of productivity. For instance PI for family living space is $2444 / 722=3.38$ Column 9: The deviation equals to means of perception index for all the 6 variables for quality of life subtracted from perception index value for each identified variables $3.38-3.50=-0.12$ for family living space .

Column 10: the Square of the Deviation Using the formula below, the variance, standard deviation and co-efficient of variation of residents' perception responses is as calculated below

Variance $==1.3481 / 5=0.269$

Standard deviation $(\mathrm{SD})==0.518$

Co-efficient of variation $=x 100 \%=x 100=$ $14.8 \%$

The highest of the residents' perception components from the likert scale output of infrastructure dimension (Housing) are; built as planned (3.95), housing affordability (3.62 ) while family living space and home satisfaction are (3.38).This explained housing as infrastructure of prosperity of respondents perception.

\section{Infrastructural Development Dimension (Public Services)}

This part of the section discussed Public Services of the Infrastructural Development in a society. This social aspect could be seen as the bedrock of prosperity. The information related to the section includes improved water, waste collection point, proximity of primary school, and proximity of secondary school, proximity of health faculties, public bus stop and regularly 
power supply. The table 4.5.3 shows the detailed results as discussed below.

\section{Perception on Improved Water Supply (Tap Water)}

Access to improved water (Tap Water) in Oke-Aro shows that; $43.5 \%$ strongly dissatisfied, 50.0\% Dissatisfied, and 6.5.0\% were Moderately satisfied, while in Otun, its shows that $86.6 \%$ strongly dissatisfied, $12.2 \%$ Dissatisfied, and $1.9 \%$ were Moderately satisfied in their response. Majority of the respondents are strongly dissatisfied with access to tap water.

\section{Perception on Accessibility and Availability of Waste Collection Points}

This result shows the availability and accessibility of waste collection points in Oke-Aro shows that; $20.4 \%$ Strongly Dissatisfied, $39.2 \%$ Dissatisfied ,17.2\% were Moderately satisfied, $20.0 \%$ Satisfied and $2.8 \%$ Strongly Satisfied, while in Otun, its shows that $18.0 \%$ Strongly Dissatisfied, $45.0 \%$ Dissatisfied ,33.2\% were Moderately satisfied and $3.8 \%$ Satisfied. Majority of the respondents are Dissatisfied, due the fact that there is no planned portion for waste collection.

\section{Perception on Proximity of Public Primary School}

This result shows the closeness of public primary schools in Oke-Aro ; $5.1 \%$ Strongly Dissatisfied, $11.8 \%$ Dissatisfied, $34.6 \%$ were Moderately satisfied, 43.7.\% Satisfied and $4.8 \%$ Strongly Satisfied, while in Otun, its shows that $4.1 \%$ were Moderately satisfied and $92.3 \%$ Satisfied and $3.6 \%$ Strongly Satisfied. Majority of the respondents are Satisfied in Oke - Aro with St. Peter African Church School, and Otun is between two Primary Schools: Ansaruldeen Primary School and Local Government Primary School Otun - Ota.

\section{Perception on Proximity of Public Secondary School}

This result shows the closeness of public secondary schools in Oke-Aro ; 5.1 $\%$ Strongly Dissatisfied, $12.7 \%$
Dissatisfied, $25.1 \%$ were Moderately satisfied, 47.0.\% Satisfied , $7.3 \%$ Strongly Satisfied and $2.8 \%$ were indifferent, while in Otun, its shows that $0.3 \%$ Dissatisfied, $4.4 \%$ were Moderately satisfied, $91.8 \%$ Satisfied and $3.5 \%$ Strongly Satisfied. Majority of the respondents satisfied because the settlement has close schools; Oke - Aro District Comprehensive College, St. Michael African Church school, A.U.D School and Iganmode High School.

\section{Perception on Proximity to Public Health} Facilities

The closeness of public health facilities in Oke-Aro shows that; $13.8 \%$ Strongly Dissatisfied, $23.7 \%$ Dissatisfied, $14.1 \%$ were Moderately satisfied, $40.6 \%$ Satisfied and $7.8 \%$ Strongly Satisfied, while in Otun, its shows that $25.3 \%$ were Moderately satisfied, $71.1 \%$ Satisfied and $3.5 \%$ Strongly Satisfied. Majority of the respondents were satisfied to have a nearby public health facilities.

\section{Perception on the Closeness of Bus Stop}

The closeness of public health facilities in Oke-Aro shows that; $8.7 \%$ Strongly Dissatisfied, $13.8 \%$ Dissatisfied, $11.0 \%$ were Moderately satisfied, $44.2 \%$ Satisfied and $22.3 \%$ Strongly Satisfied, while in Otun, its shows that $29.7 \%$ were Moderately satisfied, $66.5 \%$ Satisfied and $3.8 \%$ Strongly Satisfied. Majority of the respondents were satisfied with the closeness of bus stop and the availability of commercial motor bikes, though there is no significant built bus stop.

\section{Perception on the Regularity of Power Supply}

Regularity of power supply in Oke-Aro shows that; $35.0 \%$ Strongly Dissatisfied $13.8 \%$ Dissatisfied, $18.3 \%$ were Moderately satisfied and $14.1 \%$ Satisfied, while in Otun, its shows that $3.8 \%$ Strongly Dissatisfied, 89.4\% Dissatisfied and $6.8 \%$ were Moderately satisfied,. Majority of the respondents Dissatisfied with regular power supply in the areas. 
Table 5: Residents' perceptions of Infrastructure development (Public Services)

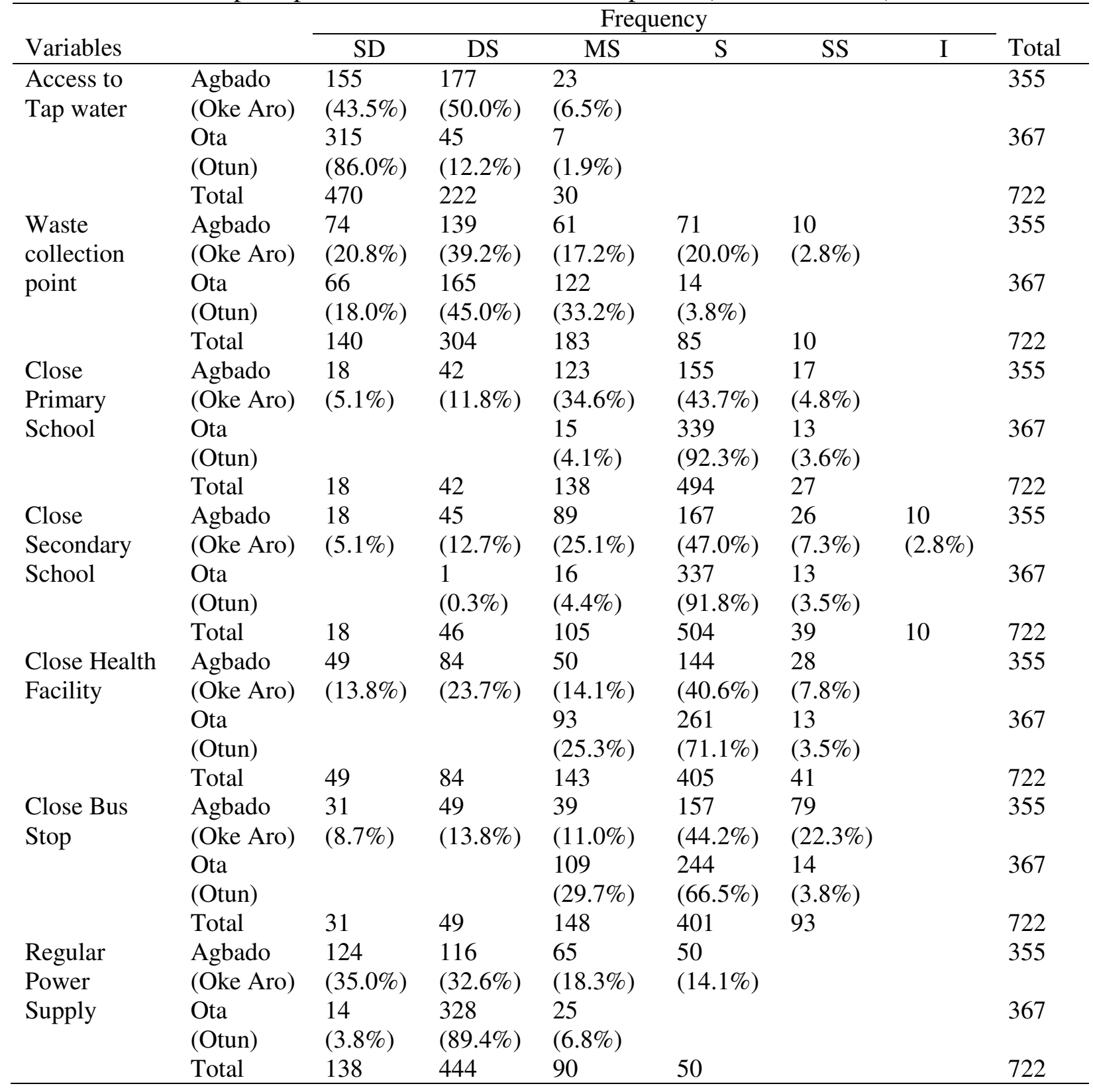


Table 6: Perception Index of Respondents' on Infrastructure Development (Public Services)

\begin{tabular}{|c|c|c|c|c|c|c|c|c|c|}
\hline \multicolumn{7}{|c|}{ Rating and Weight Value } & \multicolumn{3}{|c|}{ Deviation } \\
\hline Factors & $\mathrm{SS}(5)$ & $\mathrm{S}(4)$ & $\operatorname{MS}(3)$ & $\mathrm{DS}(2)$ & SDs(1) & SWV & RPI & RPI-PPI & (RPI-PPI) \\
\hline $\begin{array}{l}\text { Closeness to bus } \\
\text { stop }\end{array}$ & 93 & 401 & 148 & 49 & 31 & 2642 & 3.65 & 0.63 & 0.3969 \\
\hline $\begin{array}{l}\text { Closeness to } \\
\text { Secondary }\end{array}$ & 39 & 504 & 105 & 46 & 18 & 2636 & 3.65 & 0.63 & 0.396 \\
\hline $\begin{array}{l}\text { Closeness to } \\
\text { primary }\end{array}$ & 27 & 494 & 138 & 42 & 18 & 2627 & 3.63 & 0.61 & 0.3721 \\
\hline $\begin{array}{l}\text { Closeness to } \\
\text { Health facilities }\end{array}$ & 41 & 405 & 143 & 84 & 49 & 2471 & 3.42 & 0.4 & 0.1600 \\
\hline $\begin{array}{l}\text { Regular power } \\
\text { supply }\end{array}$ & 50 & 90 & 444 & 138 & & 2218 & 3.07 & 0.05 & 0.0025 \\
\hline $\begin{array}{l}\text { Waste } \\
\text { collection point }\end{array}$ & 10 & 85 & 183 & 304 & 140 & 1688 & 2.33 & -0.69 & 0.476 \\
\hline Access to Water & & & 30 & 222 & 470 & 1004 & 1.39 & -1.63 & 2.656 \\
\hline Total & & & & & & & 21.14 & & 4.4604 \\
\hline
\end{tabular}

$\mathrm{RPI}=21.14, \mathrm{PPI}=\frac{\mathrm{RPI}}{}=21.14$
$\begin{aligned}(\mathrm{N}=7) \\ =3.02\end{aligned}$

Computation of PI values in Table 6

Column 1: Factors the shows Infrastructure Development dimension (Public service) in the area

Column 2: Variables that rated strongly satisfied

Column 3: Variables that rated satisfied

Column 4: Variables that rated moderately satisfied or Moderate

Column 5: Variables that rated dissatisfied Column 6: Variables that rated strongly dissatisfied

Column 7: Addition of the variables of infrastructure development dimension (Public Service) with their levels of satisfaction and their respective weight values. For instance, for waste collection point $10(5)+85(4)+183(3)+183(2)+$ $304(1)=1688$
Column 8: Perception index of the variables of infrastructure development dimension with their levels of satisfaction and their respective weight values, equals summation of weight value (SWV) divided by the addition of individual satisfaction on the variable of productivity. For instance PI for waste collection point is $1688 / 722=$ 2.33

Column 9: The deviation equals to means of perception index for all the 7 variables for public service subtracted from perception index value for each identified variables $2.33-3.02=-0.69$ for waste collection point.

Column 10: the Square of the Deviation Using the formula below, the variance, standard deviation and co-efficient of 
variation of residents' perception responses is as calculated below

Variance $==4.4604 / 7=0.6372$

Standard deviation $(\mathrm{SD})==0.798$

Co-efficient of variation $=\mathrm{x} 100 \%=\mathrm{x} 100=$ $26.4 \%$

The highest of the residents' perception components from the likert scale output of infrastructure dimension (public service) are; closeness to bus stop (3.65), closeness to Secondary (3.65) and closeness to primary (3.63).This explained public service as development infrastructure of prosperity of respondents perception.

\section{Discussion}

The importance of sampling the RPI on provision of infrastructural facilities and services made available projects beyond the present. It forms a yardstick to check and balance adequacy and improvement of such infrastructure and facilities. This study has revealed the situation of infrastructure provided and satisfaction enjoyed by end users. A review of the RPI on health infrastructure at 3.36 and Public School standard at 3.25 shows that it is quite encouraging. However there is need for infrastructure maintenance and improvement considering the possible increase in future population.

Of greater concern is the connectivity to services which require immediate attention considering the 0.55 RPI-PPI values. The difference recorded in infrastructure adequacy and satisfaction in public schools and transportation with over $50 \%$ in the study area 1 (Oke aro) and lesser percentage in in study area 2 (Otun) shows inconsistency of perception. This remains interesting for the study. In terms of Housing, the dimension of home ownership, affordability and living space appear to be rally satisfactory with high
RPI of $3.95-3.38$. On the overall the coefficient of variation stands at $14.8 \%$ showing prosperity in housing.

Conclusively, infrastructure development dimension especially regarding water and waste reveals a very poor satisfaction of lesser percentage with coefficient with coefficient of variation at 26. 4. This is not really satisfactory.

\section{Conclusion}

The study concludes that there appear to be a general urban prosperity in terms of urban infrastructure provision. However, there is dissatisfaction with the provision of water and waste collection. Thus, for the settlements to fully enjoy urban prosperity in terms of infrastructural Development in Ota and Agbado of Ogun State, Nigeria, there is a need for infrastructure development to aid water supply as revealed in the study since the water works in Ota is non-functional. The roads under construction by the state government reflect an evidence of prospective prosperity in the study area. Increasing the sources of income to meet the daily financial needs will further boost the economic prosperity. The study recommends that there is a need for Ogun State Government to plan their urban settlements towards sustainability. Policies, laws and regulation that can bring about the change in building prosperous area needs to be revisited and implemented. Urban upgrading programme or policy is recommended to the core areas for a facelift and sustainability. Ancient structures of good architectural value could be conserved by provision of infrastructures in core areas and could be carried out by quasi-governmental efforts, to promote a functional, livable and aesthetically pleasing environment. Provision of basic services (tap water, 
waste collection point and sanitation, drainage, constant power supply, standard schools and hospital) is essential for urban prosperity and will boost productivity and enhanced value of life.

\section{References}

Adebayo, M.A. (2006). The state of urban infrastructure and its effects on property values in Lagos, Nigeria. Land Use and Development Studies, 2(1): 1-9.

Adetola, A., Goulding, J. and Liyanage, C. (2013). Public-private perception of collaborative infrastructure projects in Nigeria. International Journal of Procurement Management, 6(2): 235254.

Adeyinka, S.A. and Olugbamila, O.B. (2011). Public Private Partnership as a strategy for urban infrastructure provision in Nigeria cities. Paper presented at the 42nd Conference of the Nigerian Institute of Town Planners., Osogbo, Nigeria. 26th 29th October.

Akintoye, A., Liyanage, C., and Renukappa, S. (2011). Public Private Partnerships: Paper presented at the University of Central Lancashire, School of Built and Natural Environment, October, Preston, United Kingdom.
Ayodele, A.S. (1996). Development and management of utilities in Nigeria: Malthouse Press for the Centre for Advanced Social Science.

Babarinde, J. (1998). Analysis of Industrial relocation in relation to Housing and Infrastructural services in Metropolitan Lagos. The Lagos Journal of Environmental Studies, 1(1): 97-108.

Donald, C. (1974). Professional Education in Public Works. Environmental Engineering Administration 5th ed. Chicago. American Public works and Association. (July/August), 30-32.

Nubi, T.O. (2002). 'Procuring, managing and financing urban infrastructure: Towards integrated approach. Paper presented at the National Workshop on Land Management and Property Tax Reform in Nigeria., Akoka, Lagos.

Okusipe, M.O. (1999). Environmental quality and urban planning: A case of Metropolitan Lagos, Nigeria. Lagos Journal of Environmental Studies, 2(1), 53-63.

UN-Habitat. (2013). State of the World's Cities 2012/2013: Prosperity of cities. Routledge, New York.

Yamane, T. (1967). Elementery Sampling Theory Prentice. Hall Inc, Englewood Cliffs. 